\title{
Problematyka zależności Ukrainy od importu oleju napędowego
}

Mateusz Domian*

\section{Wstęp}

Olej napędowy (ON) pozostaje najpopularniejszym paliwem silnikowym w UE (Energy consumption in transport... 2009, Furman 30.09.2018), mimo że od 2011 r. udział w unijnym rynku pojazdów napędzanych tym paliwem szybko spada, co pokazują dane dotyczące liczby ich rejestracji. W 2019 r. pojazdy te stanowiły 30,5\% wszystkich przyjętych do ruchu, w 2018 r. - 35,9\%, a w 2011 r. - 55\% (4Q 2019: EU diesel demand continues to drop... 2020; Boner 2018). Pomimo coraz większego w Europie Zachodniej ekologicznego sprzeciwu wobec wzrostu konsumpcji ON (Mirkiewicz 9.12.2019) wskaźniki jego zużycia w Europie Środkowo-Wschodniej rosną. Pod tym względem wyróżnia się Ukraina. Od 2015 r. notuje ona ok. pięcio-, sześcioprocentowy wzrost konsumpcji tego paliwa - tylko w 2019 r. wyniósł on aż 7,3\% (Rynok motornogo topliwa... 2020). Dla porównania - zużycie ON w 2019 r. w Polsce wyniosło 20,95 $\mathrm{mln} \mathrm{m}^{3}$, tj. o 3\% więcej rok do roku (POPiHN: Zużycie paliw w Polsce... 2020). Ukraiński rynek paliw jest szczególnie interesujący ze względu na dużą dynamikę wpływających na jego funkcjonowanie wydarzeń politycznych i rynkowych, które mają swoje źródła zarówno w sporach wewnętrznych, jak i trudnych relacjach z Rosją lub są efektem silnego wpływu Rosji na rynki innych państw.

Od końca 2013 r. Ukraina znajduje się w wyjątkowo trudnym pod względem politycznym i gospodarczym położeniu. Po wielomiesięcznym paraliżu struktur państwowych w wyniku rewolucji na Majdanie Niepodległości w Kijowie (koniec listopada 2013 r.), aneksji Krymu (luty-marzec 2014 r.) oraz wybuchu wojny na wschodzie kraju (od kwietnia 2014 r.) aparat państwowy systematycznie przebudowuje prawo na wzór demokracji europejskich. Pomimo osiągnięcia

* Mateusz Domian - magister, doktorant, Szkoła Główna Handlowa w Warszawie, Kolegium Gospodarki Światowej, mateusz.domian@outlook.com. 


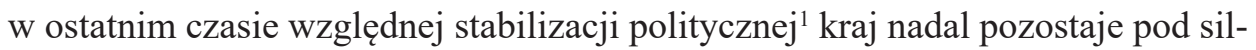
nym wpływem gospodarczym Rosji, która przez obecny establishment polityczny Ukrainy jest postrzegana jako źródło większości problemów państwa. Najbardziej wymownym przykładem tego wpływu był wysoki udział importu rosyjskich paliw silnikowych na Ukrainie w 2019 r., który wyniósł 29,4\%² ogólnego zużycia.

Podobny udział miał import paliw z Białorusi (31,9\%), który z powodu całkowitego uzależnienia białoruskiego przemysłu rafineryjnego od dostaw ropy naftowej z Rosji postrzegany jest jako pośredni kanał wpływu rosyjskiego na płynność rynku paliw Ukrainy. Potwierdziły to ostatnie wydarzenia, a mianowicie pojawienie się w rurociągu Przyjaźń zanieczyszczonej rosyjskiej ropy naftowej

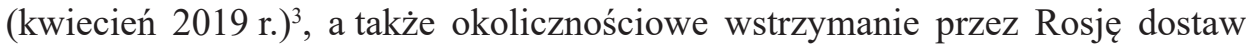
surowca do białoruskich rafinerii (pierwszy kwartał 2020 r.). Oba te wydarzenia poskutkowały natychmiastowymi decyzjami strony białoruskiej o ograniczeniu eksportu paliw na Ukrainę.

Autor, chcąc dokładniej przeanalizować kondycję ukraińskiego rynku oleju napędowego, podejmuje się rozwiązania problemu badawczego, jakim jest skwantyfikowanie poziomu zależności ukraińskiego rynku oleju napędowego od importu tego paliwa z Rosji i Białorusi w latach 2010-2019. Przyjęcie za okres badawczy tej dekady wynika z chęci odniesienia się do lat możliwie bliskich współczesności, a rozpoczęcie badania od roku późniejszego niż 2010 byłoby ryzykowne, ponieważ rok referencyjny zostałby ustanowiony zbyt blisko kryzysu z lat 2013-2014 (dynamiczne przemiany polityczne na Ukrainie, wybuch wojny w Donbasie). Rok 2019 to z kolei ostatni rok, w którym opublikowano najbardziej aktualne dane niezbędne do napisania niniejszego artykułu. Do przeprowadzenia badania wykorzystano metodę analizy koncentracji rynku przy użyciu wskaźnika Shannona-Wienera oraz współczynnika Giniego.

Za cel artykułu autor przyjął przybliżenie czytelnikowi sytuacji na ukraińskim rynku ON ze szczególnym uwzględnieniem zagrożeń wynikających z jego ograniczonej autonomii.

W osiągnięciu tego celu ma pomóc weryfikacja hipotezy, zgodnie z którą fundamentalnym wyzwaniem dla bezpieczeństwa ukraińskiego rynku oleju

\footnotetext{
${ }^{1}$ Chociaż nadal nie udało się zakończyć walk w Donbasie, w wyniku przeprowadzonych w kwietniu 2019 r. demokratycznych wyborów odbyło się pierwsze po 2014 r. pokojowe przekazanie władzy przez dotychczasowego prezydenta Petra Poroszenkę nowo wybranemu Wołodymyrowi Zełenskyemu.

2 3,194 mln t zużytych paliw (na 10,86 mln t) pochodziło z Rosji (Wykres 1), w tym olej napędowy $-2,5$ mln t (Ukrainskij rynok DT priblizitsia ... 2020) oraz LPG (ang. liquefied petroleum gas) - 0,694 mln t (Ukrainskij rynok sżyżennogo gaza... 2020). W ubiegłym roku Ukraina nie sprowadzała z Rosji benzyny i paliwa lotniczego.

${ }^{3}$ Rurociąg Przyjaźń (ros. nieftieprowod Drużba) - system rurociągów łączący Federację Rosyjską z Europą, będący głównym kanałem zaopatrywania Europy Środkowo-Wschodniej w rosyjską ropę naftową.
} 
napędowego pozostaje wysoki współczynnik koncentracji udziału w tymże rynku paliwa z Rosji oraz Białorusi (z powodu jej silnych związków handlowych z Rosją). Trudne relacje polityczne między Ukrainą a Rosją, w szczególności po wydarzeniach z lat 2013 i 2014, nie zaowocowały trwałym zminimalizowaniem wpływu rosyjskich producentów na ukraiński rynek ON. Tylko w ciągu ostatnich kilkunastu miesięcy spory między Ukrainą a Rosją oraz niejednoznaczne stosunki Rosji z Białorusią doprowadziły do nagłych wydarzeń, takich jak sankcje czy problemy z dostawami ropy, które w sposób bezpośredni (w relacjach Ukrainy z Rosją) bądź pośredni (w wyniku problematycznych stosunków między Mińskiem a Moskwą) natychmiastowo uderzały w kondycję ukraińskiego rynku oleju napędowego. Wspólnym mianownikiem tych wydarzeń była Rosja, która dzięki swojej silnej pozycji producenta paliw stale zachowuje znaczącą swobodę w dyktowaniu warunków współpracy m.in. właśnie Ukrainie.

\section{Dostępność oleju napędowego jako element bezpieczeństwa energetycznego kraju}

Podejmowana w artykule zależność ukraińskiego rynku oleju napędowego od dostaw tego paliwa z zewnątrz ma, w szerszym kontekście, niewątpliwy wpływ na bezpieczeństwo energetyczne kraju. W literaturze funkcjonuje kilka rodzajów definicji terminu „bezpieczeństwo energetyczne”. Zważywszy na przyjęty problem badawczy, najlepszym podejściem będzie przeanalizowanie tego rodzaju bezpieczeństwa $\mathrm{w}$ odniesieniu do problematyki pochodzenia energii ( $\mathrm{Ny}-$ ga-Łukaszewska 2019) $)^{4}$ czy też dywersyfikacji źródeł dostaw nośników energii (Mrówka 2012) ${ }^{5}$. O bezpieczeństwie energetycznym powiemy więc, że jest to „zdolność systemu gospodarczego państwa do zapewnienia dostępności do surowców [paliw] ze źródeł krajowych i zagranicznych na poziomie (i o strukturze) odpowiadającym potrzebom gospodarki i społeczeństwa, a zarazem gwarantującym potencjał do przeciwstawienia się naciskom zewnętrznym oraz niezagrożony rozwój gospodarki narodowej" (Młynarski 2011). Na podstawie tej definicji słuszne wydaje się doprecyzowanie terminu „bezpieczeństwo rynku", tj. rynku paliw Ukrainy, który bardzo często pojawia się w tekście niniejszego artykułu. Autor rozumie bezpieczeństwo rynku jako stan, w którym rynek

\footnotetext{
${ }^{4}$ H. Nyga-Łukaszewska dzieli definicje bezpieczeństwa energetycznego na cztery grupy, które skupiają się na odmiennych kwestiach: wspomnianym pochodzeniu energii, szacowaniu kosztów przerw w dostawach energii, zróżnicowanych kryteriach, m.in. geopolitycznych i geoekonomicznych, akceptowalności, oraz na zagrożeniach odnoszących się do bezpieczeństwa energetycznego.

5 Według A. Mrówki bezpieczeństwo energetyczne można analizować w podziale na następujące kategorie: dywersyfikację źródeł dostaw nośników energii, zróżnicowanie krajowego bilansu paliwowego oraz dostęp do infrastruktury przesyłu, magazynowania i dystrybucji paliw oraz energii.
} 
ten, wykorzystując produkcję własną oraz import, zachowuje zdolność do ciągłego zabezpieczania potrzeb konsumenta oraz przeciwstawiania się naciskom zewnętrznym, np. w wyniku dywersyfikacji dostaw.

Jednym $\mathrm{z}$ atrybutów bezpieczeństwa energetycznego, w tym bezpieczeństwa rynku paliw, jest polityczna niezależność dostaw będąca elementem polityki energetycznej państwa, a dokładniej - strategii rządu zorientowanej na zarządzanie obecną i przyszłą równowagą energetyczną państwa (Prontera 2009). Można się zgodzić, że „zapewnienie dostępu do energii w różnych jej postaciach stanowi główne wyzwanie strategii gospodarczej każdego współczesnego rządu, który, chcąc utrzymać się przy władzy, powinien zapewniać swoim obywatelom odpowiednie warunki egzystencji, a przedsiębiorcom - odpowiednie warunki prowadzenia działalności gospodarczej” (Tomaszewski 2014).

Słowo wyjaśnienia autor pragnie poświęcić tytułowemu terminowi, jakim jest zależność Ukrainy od importu oleju napędowego. Jest on pochodną koncepcji zależności ekonomicznej, którą określa asymetria relacji handlowych (Nyga-Łukaszewska 2019). Zależność ekonomiczna może być importowa bądź eksportowa (Czech 2018). Pierwsza z nich, czyli zależność importowa, której poświęcony jest artykuł, to „sytuacja, w której państwo nie ma możliwości zaspokajania swoich potrzeb (...) w 100\% ze źródeł krajowych" (Pronińska 2013). Występuje wtedy zależność jednostronna, tj. zależność jednego państwa od innego, bądź wielostronna, czyli pojedynczego państwa od kilku innych, a także - w odniesieniu do przedmiotu zależności - handlowa, kapitałowa i technologiczna. Zależność handlowa dotyczy obrotu towarami, a na podstawie ich rodzajów wyróżnia się kolejne odmiany tego typu zależności: energetyczną, surowcową, żywnościową i finansową. Uzależnienie kraju od importu paliw kwalifikuje się jako zależność energetyczną (Nyga-Łukaszewska 2019).

Zaprezentowana w niniejszym artykule analiza zróżnicowania udziałów w ukraińskim rynku ON, w tym analiza stopnia jego zależności od importu tego paliwa, jest nową okolicznością w badaniach nad ukraińskim rynkiem paliw silnikowych. Mimo że dostępność ON jest jednym z kluczowych warunków przetrwania ukraińskiej gospodarki, produkt ten nie był dotychczas popularnym przedmiotem badań w miejscowej literaturze. Kwestia dominującej pozycji Rosji w energetyce regionalnej oraz jej konsekwencje dla państw ościennych są wprawdzie znane zarówno badaczom ukraińskim (Własiuk 2016; Mazur 2014; Matwijczuk 2018), jak i zagranicznym (Austvik 2015; Rodriguez-Fernandez i in. 2020; Sauvageot 2020), jednak problem ten był rzadko analizowany w odniesieniu do ukraińskiego rynku ON. Ostatnie odnotowane przez autora prace poruszające tę tematykę dotyczyły okresu sprzed 2013 r. (Dronowa 2010; Teletow i in. 2013), ale do tej pory nie była ona analizowana przy użyciu narzędzi wykorzystanych na potrzeby niniejszego artykułu. 


\section{Charakterystyka ukraińskiego rynku ON}

\section{Struktura konsumpcji paliw na Ukrainie}

Analizę rynku ON Ukrainy należy rozpocząć od przestudiowania całej struktury krajowej konsumpcji paliw. Najbardziej aktualne dane z tego zakresu prezentuje Załącznik 1.

Coraz większą popularnością cieszą się wśród Ukraińców olej napędowy (stały wzrost od 2014 r.) oraz LPG (wzrost od 2004 r.). Począwszy od 2015 r., kiedy to ze względu na problemy gospodarcze kraju odnotowano na jego terytorium najniższą z dotychczasowych wartość legalnej konsumpcji paliw, zużycie ON oraz LPG wzrosło do 2019 r. kolejno o $28 \%$ i $71 \%$. Oba te rodzaje paliw stanowią łącznie $82 \%$ krajowego rynku, tj. o $49 \%$ więcej w porównaniu z rokiem 2008 i o 8\% - z rokiem 2015 (patrz: Załącznik 1). Wzrost ten nastąpił kosztem benzyny, której konsumpcja z roku na rok spada (o 62\% od 2008 r. oraz o $6 \%$ od 2015 r.). Dzieje się tak, ponieważ przy zakupie paliw, a wcześniej przy zakupie pojazdów, ukraińscy klienci kierują się z reguły ich ceną - wybierają paliwo o najkorzystniejszym stosunku wartości detalicznej pojedynczej jego jednostki do liczby kilometrów, które można pokonać w wyniku jej spalenia. W takiej sytuacji korzystniej wypadają LPG i ON (Burda 2.05.2006).

\section{Ukraiński import oleju napędowego z Rosji}

Rosyjski kierunek zajmuje zdecydowanie kluczową rolę w strukturze zaopatrzenia Ukrainy w olej napędowy, co wyraźnie pokazuje Wykres 1. Olej z Rosji dociera na Ukrainę rurociągiem produktowym Prikarpatzapadtrans (PZT) oraz drogą kolejową.

Ze względu na istotne znaczenie dla miejscowego rynku ON rurociąg PZT stanowi przedmiot ścierania się interesów stron ukraińskiej i rosyjskiej. Został on uruchomiony w 2016 r. i do sierpnia 2019 r. był podstawowym źródłem zaopatrzenia ukraińskich konsumentów w olej napędowy, co wynikało zarówno z niskiego kosztu logistyki, jak i niemalże nieograniczonej dostępności produktu. Tylko w 2019 r. za pośrednictwem rurociągu PZT dotarło na Ukrainę 1,23 mln t $(49,2 \%)$ rosyjskiego ON. Pozostałe $1,27 \mathrm{mln} \mathrm{t}$ eksportowano drogą kolejową. W lipcu 2019 r. strona ukraińska, chcąc chronić krajowy rynek oleju napędowego przed wzrostem udziału w nim produktu rosyjskiego, przyjęła sankcje ograniczające import rosyjskich paliw, w tym oleju napędowego z $\mathrm{PZT}^{6}$ (Import diztopliwa

${ }^{6}$ Ograniczenia oznaczały wprowadzenie dodatkowej taryfy na zakup pochodzącego z rurociągu rosyjskiego ON. Od 1.08.2019 r. było to 3,75\% wartości celnej produktu oraz 4\% od 1.10.2019 r. Wynikało to ze wzrostu cen produktu o ok. 26-30 USD/t (Poszliny nie priwiedut k rostu cen... 2019). 
w ijule... 2019). Decyzja ta spotkała się z szybką odpowiedzią - już w pierwszych dniach obowiązywania sankcji operator PZT całkowicie wstrzymał sprzedaż oleju napędowego na Ukrainie, tłumacząc to niską efektywnością handlu (Muravski 27.08.2019). Zamknięcie tego kanału doprowadziło do zmian w udziale pozostałych źródeł ON na ukraińskim rynku, co obrazuje Wykres 2. Dopiero w grudniu 2019 r. operator oddał do sprzedaży pierwszą partię ON, jednak w ograniczonej ilości ok. $30 \mathrm{kT}$ - przed wprowadzeniem sankcji było to ponad $100 \mathrm{kT}$ miesięcznie (DT dieszewiejet w ożydanii... 2019).

Wykres 1. Źródła dostaw oleju napędowego na rynek ukraiński w latach 2018 i 2019
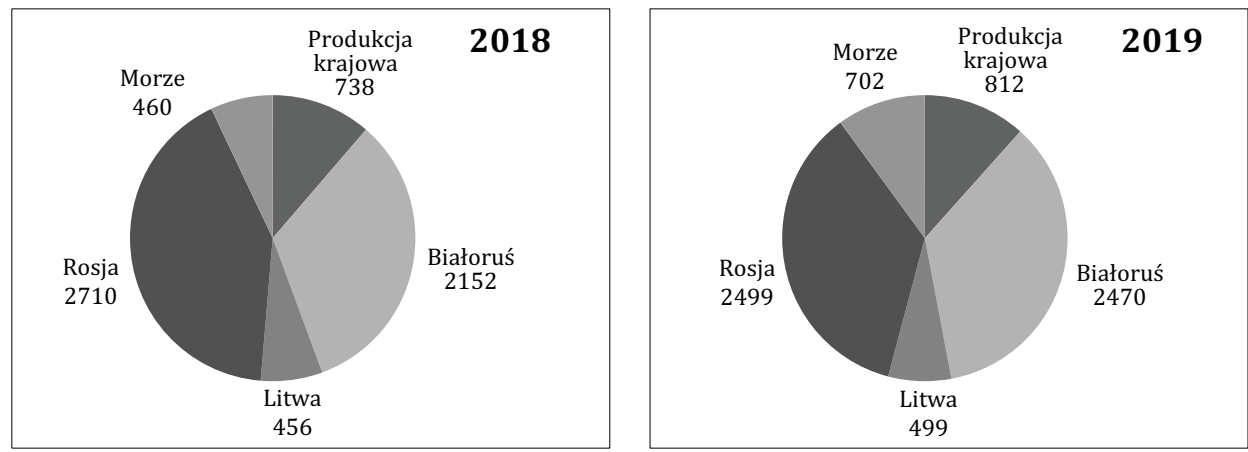

Źródło: opracowanie własne na podstawie Ukrainskij rynok DT pribliziłsia .. 13.01.2020.

Olej napędowy z Rosji dociera na Ukrainę również drogą kolejową. W przeciwieństwie do Prikarpatzapadtrans spory rynkowe i polityczne nie mają wpływu na tę metodę transportu - do końca pierwszej połowy 2019 r. na terytorium Ukrainy dotarło w ten sposób $396 \mathrm{kT}$ rosyjskiego produktu ${ }^{7}$, a w drugiej połowie roku było to już $1270 \mathrm{kT}$, czyli o $121 \%$ więcej w porównaniu z poprzednim półroczem. Nagły wzrost zainteresowania tą metodą transportu był spowodowany zamknięciem PZT.

\footnotetext{
${ }^{7} \mathrm{~W}$ tym $270 \mathrm{kT}$ ze stacji odbioru produktu zlokalizowanej na białoruskim odcinku PZT w Homlu. Ukraińskie sankcje nie objęły rosyjskiego ON z PZT sprzedawanego na terytorium Białorusi i dostarczanego na Ukrainę drogą kolejową.
} 
Wykres 2. Zmiany w udziale poszczególnych kanałów dostaw oleju napędowego na rynek Ukrainy po zamknięciu PZT $^{8}$

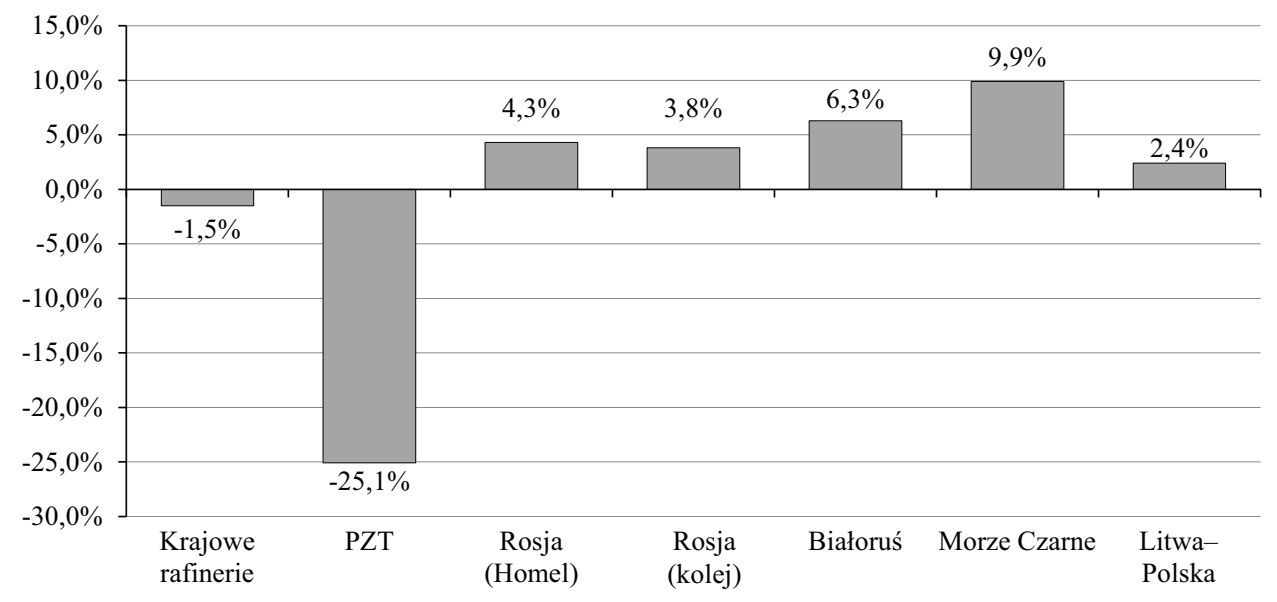

Źródło: opracowanie własne na podstawie danych zaprezentowanych na konferencji Petroleum Ukraine 2019 w dniach 12-13.11.2019 r. w Kijowie

\section{Import oleju napędowego z Białorusi}

Olej napędowy pochodzący z Białorusi trafia na ukraiński rynek drogą kolejową i jest dla Ukrainy nie mniej ważny od rosyjskiego. W 2019 r. Ukraina sprowadziła z białoruskich rafinerii $2470 \mathrm{kT}$ produktu, tj. o 14,8\% więcej niż rok wcześniej (Wykres 1). Rozwiązanie to wydaje się logiczne, zwłaszcza że dostawy z Białorusi zapewniają Ukrainie najlepsze warunki zarówno logistyczne, jak i cenowe ${ }^{9}$. Nie towarzyszą im ponadto, przynajmniej nie bezpośrednio, regularne napięcia polityczne pomiędzy stronami transakcji, które występują między Kijowem a Moskwą i zwiększają ryzyko utraty płynności importu rosyjskiego ON na Ukrainę. Relatywnie niski koszt białoruskiego ON jest wynikiem korzystania przez

\footnotetext{
${ }^{8}$ Stan na połowę listopada 2019 r. Krajowe rafinerie - rafineria w Krzemieńczuku i szebelińskie zakłady przetwórstwa kondensatu gazowego; PZT - rurociąg Prikarpatzapadtrans; Rosja (Homel) - dostawy rosyjskiego ON ze stacji na rurociągu produktowym w białoruskim Homlu; Rosja (kolej) - dostawy ON koleją bezpośrednio z Rosji; Morze Czarne - całość ON docierająca do kraju za pośrednictwem portów morskich Ukrainy.

9 W połowie lutego 2019 r. (13.02) cena SPOT wg ARGUS Ukraine FCA na białoruski ON z zakładu w Mozyrzu (967 USD/t) była wyższa o 8 USD/t od ceny za rosyjski produkt z PZT, ale niższa o $29 \mathrm{USD} / \mathrm{t}$ od produktu litewskiego oraz o $40 \mathrm{USD} / \mathrm{t}$ od produktu z morza. W czerwcu (18.06) notowania białoruskiego ON (955 USD/t) były już niższe od wszystkich pozostałych kierunków importu - o 4 USD/t od ceny produktu rosyjskiego z PZT, o $15 \mathrm{USD} / \mathrm{t}$ od litewskiego oraz o $49 \mathrm{USD} / \mathrm{t}$ od produktu z morza. Ceny te są jedynie przykładami różnic - notowania produktów aktualizowane są każdego dnia. Zeszłoroczna cena białoruskiego oleju napędowego nie zawsze była najniższa, jednak zazwyczaj był on tańszy średnio o kilkanaście USD/t od produktu z Litwy oraz o kilkadziesiąt USD/t od ON z morza.
} 
rafinerie w Mozyrzu i Nowopołocku niemalże wyłącznie z rosyjskiej ropy naftowej, którą pozyskują po wyjątkowo niskiej cenie dzięki bliskim relacjom z Rosją - w 2019 r. było to ok. 83\% ceny światowej. Ponadto bezpośrednie sąsiedztwo Białorusi sprawia, że koszt dostaw jej produktu na Ukrainę jest z reguły niższy niż produktu litewskiego lub pochodzącego z morza.

Mimo to zakup białoruskiego oleju napędowego nie jest z punktu widzenia Ukrainy pozbawiony ryzyka. Wynika ono ze wspomnianej już silnej zależności białoruskiego przemysłu rafineryjnego od dostaw ropy naftowej z Rosji. Tylko w ciągu ostatnich kilkunastu miesięcy miały miejsce dwie sytuacje, które skłoniły białoruskich producentów paliw do ograniczenia eksportu na Ukrainę:

- Pojawienie się w rurociągu Przyjaźń zanieczyszczonej rosyjskiej ropy naftowej (Czto izwiestno i czto skrywajut... 8.05.2019). Wadliwy surowiec stanowił zagrożenie dla instalacji rafineryjnych $\mathrm{w}$ przypadku podjęcia próby przerobienia, przez co konieczne było natychmiastowe zamknięcie jego dopływu do zakładów. Ponieważ dwie białoruskie rafinerie korzystały wówczas wyłącznie z dostaw surowca z Rosji, zdarzenie określono jako tzw. siłę wyższą (force majeure), usprawiedliwiając w ten sposób podjęcie nadzwyczajnych kroków wobec kontrahentów, w tym ukraińskich. W efekcie strona białoruska poinformowała o wstrzymaniu eksportu paliw na Ukrainę (Biełarus' priostanowiła eksport... 23.04.2019). Szczęśliwie dla ukraińskiego rynku już po kilku dniach udało się oczyścić jeden z przewodów rurociągu i zażegnać kryzys (Biełarus' czasticzno wozobnowita eksport... 25.04.2019).

- Ograniczenie przez Rosję z początkiem 2020 r. dostaw ropy naftowej do białoruskich rafinerii. Powyższe nastąpiło na skutek braku porozumienia stron w zakresie warunków przedłużenia kontraktu (Bakhtina $\mathrm{i}$ in. 3.01.2020). Również i tym razem Białoruś została zmuszona do zasadniczego zmniejszenia eksportu oleju napędowego własnej produkcji m.in. na Ukrainę - łącznie w styczniu i lutym 2020 r. o ok. 42\% w porównaniu z rokiem poprzednim (Wykres 3). W efekcie kraj ten stracił dotychczasową część ukraińskiego rynku, która z 33,6\% w styczniu i lutym 2019 r. zmalała w kolejnym roku do $22,4 \%$, głównie na rzecz Rosji - w styczniu i lutym 2020 r. udział rosyjskiego produktu w ukraińskim rynku wzrósł do 44,1\% (z 35,8\% za cały 2019 r.) (Rossija kompiensirowała spad... 11.03.2020).

Białoruś ma możliwość nabycia ropy ze źródeł innych niż Rosja, jednak cena takiego surowca, wraz z kosztem sprowadzenia, będzie dużo wyższa od ceny tej samej ilości ropy rosyjskiej (Biełarus'gotowa pokupat' nieft'... 21.01.2020). Zakup ropy droższej niż rosyjska spowodowałby wzrost kosztów produkcji paliw 
silnikowych w białoruskich zakładach, co z czasem doprowadziłoby do wzrostu cen hurtowych tych paliw, automatycznie zagrażając ich konkurencyjności cenowej na rynkach zagranicznych.

Wykres 3. Struktura ukraińskiego rynku oleju napędowego w styczniu/lutym w latach 2019 i $2020, \mathrm{w} \mathrm{kT}^{10}$

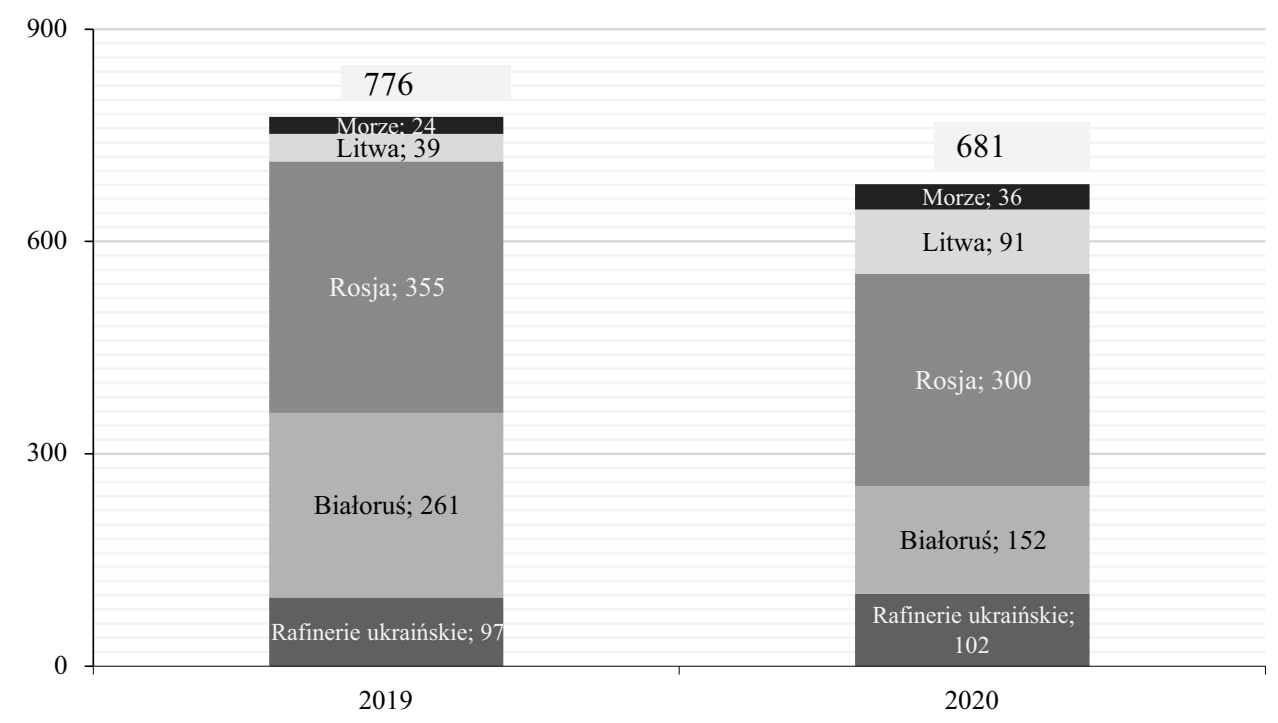

Źródło: opracowanie własne na podstawie Kuyun 28.02.2020.

\section{Import oleju napędowego z Litwy}

Trzecim dostawcą oleju napędowego na Ukrainę jest rafineria w litewskich Możejkach. Ww. olej napędowy traktowany jest przez ukraińskiego dystrybutora przede wszystkim jako produkt dywersyfikujący jego koszyk zakupowy (Omielan i Gierus rasskazali o... 6.08.2019). Dociera on na Ukrainę drogą kolejową. Pokonuje tym sposobem znacznie dłuższą trasę niż ON produkowany w białoruskim zakładzie w Mozyrzu (ok. 1 tys. km w porównaniu do ok. $70 \mathrm{~km}$ ). Z tego też względu produkt ten pozostaje relatywnie droższy dla ukraińskiego kupującego. Jednocześnie jest on jednak dostępny niezależnie od relacji w układzie Ukraina-Rosja-Białoruś. W związku z tym, mimo z reguły wyższej ceny (patrz: przypis 9), pod koniec 2019 r. do produktu litewskiego należało, podobnie jak w poprzednich latach, $7 \%$ ukraińskiego rynku ON. Było to jednocześnie 8\% całego rocznego importu ON na Ukrainę - w 2018 r. kierunek litewski zajmował odpowiednio 6,9\% ukraińskiego rynku ON i 7,8\% rocznego jego importu (Wykres 1).

${ }^{10}$ Dane za okres od 1.01 .2020 r. do 23.02 .2020 r. 


\section{Morski kierunek importu ON na Ukrainę}

Ostatnim kierunkiem importu oleju napędowego na Ukrainę jest Morze Czarne. Produkt dociera do kraju głównie za pośrednictwem portów odeskiego i południowego (Port Odiessy wiernut pierwienstwo po... 16.07.2019). W ten sposób Ukraina odbiera ON m.in. z Turcji (SOCAR), Grecji (Hellenic Petroleum) czy Turkmenistanu (Turkmenbasza) (Skywalk i BB ENERGY postawiat w... 19.08.2019). Cena produktu jest głównym czynnikiem stymulującym handel za pośrednictwem ukraińskich portów. Po stronie kupującego pozostają dodatkowe koszty frachtu i przeładunku produktu do cystern samochodowych bądź kolejowych, co powoduje, że jest on z reguły najdroższy dla ukraińskiego kupującego (patrz: przypis 9). Podobnie jak w przypadku paliwa litewskiego, producenci oraz pośrednicy dostarczający je do ukraińskich terminali morskich nie są zależni od relacji Ukrainy z Rosją czy Białorusią. I chociaż duży wpływ na pracę w ukraińskich portach, np. tempo bądź kolejność rozładunku, ma zjawisko korupcji (Korrupcyja w portach i złoupotrieblenija... 17.07.2019), to skala zakupów oleju napędowego docierającego na Ukrainę drogą morską wzrasta. W poprzednim roku udział tego paliwa w rynku wyniósł $10,1 \%$ oraz $11,4 \%$ w jego krajowym imporcie (Wykres 1 ), co było spowodowane wprowadzeniem przez ukraińskie władze sankcji na ON z PZT (Wykres 2).

\section{Metoda badawcza}

W badaniu wykorzystano dane z lat 2010-2019 dotyczące bilansu ukraińskiego rynku ON (Załącznik 2), a do ich przeanalizowania wykorzystano wskaźnik Shannona-Wienera (SW) oraz współczynnik Giniego (GC - Gini Coefficient), które są tradycyjnymi narzędziami mierzenia konkurencyjności (Kryzia 2016, s. 52-53; Bożyk i in. 2013, s. 14-15). Wybór tych narzędzi podyktowany był zamiarem zaprezentowania rezultatów z dwóch perspektyw: koncentracji rynku oleju napędowego Ukrainy, co obrazuje wskaźnik SW, oraz rozproszenia w ukraińskim imporcie ON (współczynnik GC). Za pomocą tych wskaźników badano dotychczas m.in. konkurencyjność na światowym rynku gazu ziemnego (Kryzia 2016) czy siłę rynkową w sektorze elektroenergetycznym (Kamiński 2009).

Wyniki dla wskaźnika SW wyliczono na podstawie wzoru:

$$
S W=-\sum_{i=1}^{N}\left(x_{i} \cdot \ln \left(x_{i}\right)\right)
$$

gdzie $x$ oznacza udział podmiotu w rynku, a $N$ liczbę podmiotów. 
Aby wyznaczyć SW, posłużono się danymi dotyczącymi zarówno krajowej (ukraińskiej) produkcji ON, jak i jego importu. Dzięki temu poziom koncentracji według SW pokazuje zróżnicowanie całego krajowego rynku, tj. porównuje znaczenie paliwa własnej produkcji (składowej, której wzrost wpływa na zmniejszenie wrażliwości rynku paliw Ukrainy) ze znaczeniem paliwa importowanego z Rosji czy Białorusi (składowej potencjalnie zwiększającej tę wrażliwość). SW przyjąłby wartość „,0” w sytuacji, w której istniałoby tylko jedno źródło pochodzenia ON.

W przypadku GC do obliczeń wykorzystano wyłącznie dane roczne dotyczące ukraińskiego importu ON, bez produkcji krajowej, aby zobrazować nierówności występujące jedynie w sferze zaopatrzenia kraju w produkt z zewnątrz.

Wyniki dla GC uzyskano ze wzoru:

$$
G C=\frac{\sum_{i=1}^{N} \sum_{j=1}^{N}\left|x_{i}-x_{j}\right|}{2 N^{2} \cdot \frac{\sum_{i=1}^{N} x_{i}}{N}}
$$

gdzie $x$ oznacza udział podmiotu w rynku, a $N$ liczbę podmiotów.

Im wartość GC jest bliższa „1”, tym większe występują nierówności w rozkładzie udziałów w rynku.

\section{Omówienie wyników badań}

Wskaźnik Shannona-Wienera dla rynku oleju napędowego Ukrainy (SWUA) w latach 2010-2019 waha się między 1,14 pkt w 2010 r., kiedy to zróżnicowanie źródeł było najniższe, a 1,68 pkt w roku 2013, w którym zróżnicowanie było najwyższe; obrazują to dane zawarte w Tabeli 1. Pod koniec 2019 r. wskaźnik ten wzrósł, w porównaniu z rokiem 2010, o 0,27 pkt, tj. o 23,7\%. Aby rozwiązać problem badawczy, czyli skwantyfikować poziom zależności rynku ON Ukrainy od dostaw tego paliwa z zagranicy, konieczne jest zaobserwowanie wpływu aktywnych kierunków jego pochodzenia na wartość SWUA.

Najniższy wpływ importu rosyjskiego ON (dalej określany również jako tzw. składnik rosyjski, SR) na bieżącą wartość wskaźnika Shannona-Wienera dla rynku ON Ukrainy odnotowano w 2016 r. (0,2 pkt), a następnie w latach 2013 i 2015 (po $0,21 \mathrm{pkt})$, najwyższy natomiast w roku $2010(0,29 \mathrm{pkt})$. W porównaniu z tym okresem wpływ SR na wskaźnik zróżnicowania SWUA pod koniec 2019 r. zmalał do 0,26 pkt, tj. o 10,3\% (Tabela 1 i Wykres 4). Z analizy stosunku SR do SWUA wyraźnie wynika, że był on zwykle równy $(2010,2013,2017-2019)$ bądź nieco niższy od tej samej wartości odnoszącej się do białoruskiego importu ON 
(składnik białoruski, SB). W porównaniu ze wszystkimi składowymi SWUA (poza SR i SB są to również składniki litewski, morski oraz produkcji krajowej) średnia wartość SR w badanych latach wyniosła 0,24 pkt i była kolejną po najwyższej białoruskiej ( $0,25 \mathrm{pkt})$. Warto zauważyć, że drastyczne obniżenie udziału SR w SWUA nastąpiło po latach 2013-2014, które zapoczątkowały rewolucję polityczną i wybuch wojny w Donbasie. W roku 2015 odnotowano jeden z najniższych wyników stosunku SR do SWUA oraz wysoki wynik samego SWUA (1,61 pkt do 1,48 pkt w 2014 r.), co oznacza, że 2015 był pierwszym rokiem po okresie przemian politycznych, w którym ukraiński rynek ON zmniejszył swoje uzależnienie od dostaw z Rosji oraz zwiększył import produktu z innych kierunków. Proces ten zakończył się niestety w 2016 r. - stosunek SR do SWUA zmniejszył się do 0,2 pkt, ale przy jednoczesnym obniżeniu samego SWUA do 1,56 pkt, tj. o 3,1\%. W 2017 r., czyli w pierwszym pełnym roku po uruchomieniu sprzedaży rosyjskiego ON z rurociągu Prikarpatzapadtrans, import rosyjskiego oleju drastycznie wzrósł (o $0,06 \mathrm{pkt}$, do $0,26 \mathrm{pkt}$, tj. o $30 \%$ w porównaniu z rokiem poprzednim), a stopień zróżnicowania dostaw ponownie się zmniejszył - z 1,56 pkt do 1,42 pkt, czyli o $9 \%$ ).

Tabela 1. Wskaźnik Shannona-Wienera dla zróżnicowania ukraińskiego rynku oleju napędowego za lata 2010-2019

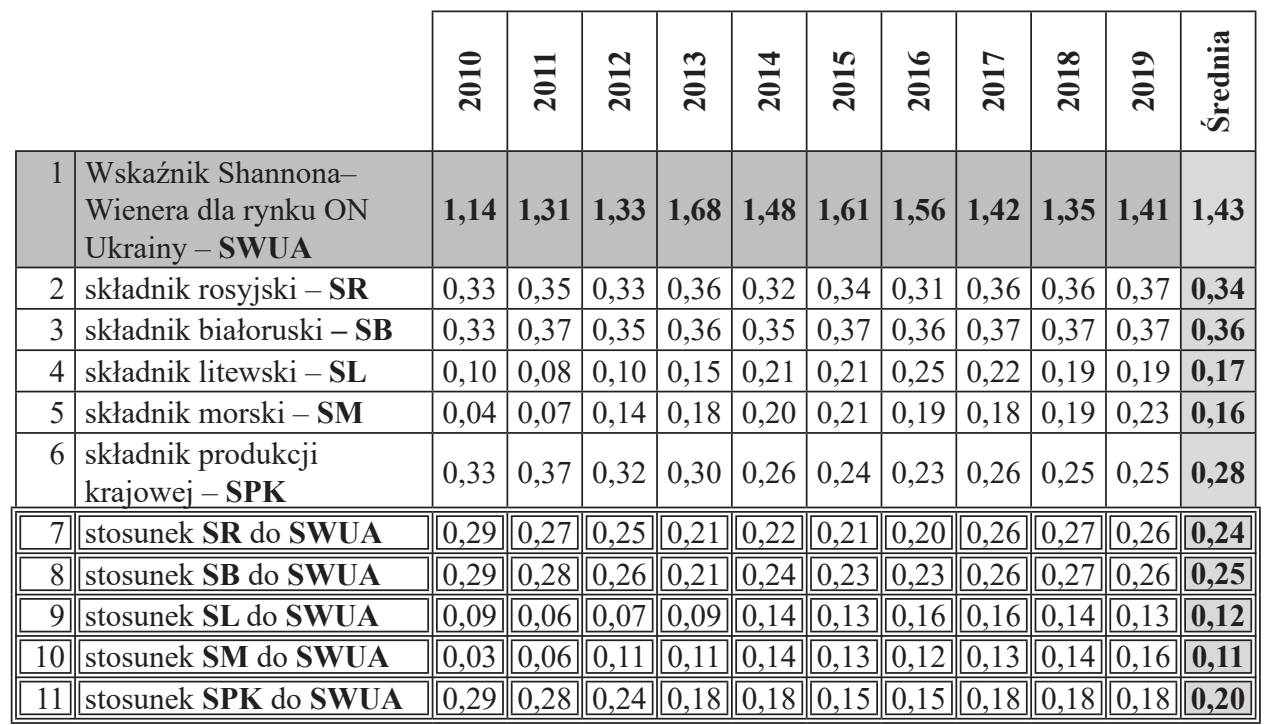

Źródło: opracowanie własne.

Największy średni wpływ na zróżnicowanie ukraińskiego rynku ON w badanym okresie miał wspomniany już kierunek białoruski - stosunek składnika białoruskiego do wskaźnika Shannona-Wienera dla ukraińskiego rynku ON wyniósł średnio 0,25 pkt. Pod koniec 2019 r. pozostał on najwyższy mimo ogólnego 
spadku wartości składnika białoruskiego w stosunku do SWUA z 0,29 pkt do 0,26 pkt, czyli o $10,3 \%{ }^{11}$ (Tabela 1 i Wykres 4). Największy spadek znaczenia SB dla SWUA odnotowano w roku 2013 (0,21 pkt). Od tego momentu w miarę regularnie odzyskiwał on straty i wzrósł ostatecznie o 23,8\% na koniec $2019 \mathrm{r}$. W świetle problemu badawczego oznacza to, że po gwałtownych wydarzeniach politycznych białoruski kierunek importu oleju napędowego nie utracił swojej części ukraińskiego rynku. W przeciwieństwie do SR, który w porównaniu z rokiem 2013 (0,21 pkt) w latach 2015 i 2016 zanotował wartości podobne i niższe (kolejno 0,21 i 0,2 pkt), SB w tym samym czasie wzrósł o 0,02 pkt, do 0,23 pkt.

Począwszy od 2010 r., udział produkcji krajowej ON (składnik produkcji krajowej, SPK) w ukraińskim rynku tego paliwa zmalał o 37,9\% (koniec 2019 r.) w stosunku do SWUA - z 0,29 pkt do 0,18 pkt (Tabela 1 i Wykres 4). Rok 2010 był również tym, w którym SPK miał najwyższy wpływ na wartość SWUA $-28,9 \%$, jednak od tego momentu zaczął on regularnie spadać. Średni stosunek SPK do wskaźnika Shannona-Wienera dla rynku ON Ukrainy wyniósł 0,2 pkt, co uplasowało go na trzeciej pozycji w zestawieniu najsilniejszych składników SWUA, za Białorusią ( 0,25 pkt) i Rosją ( 0,24 pkt).

Wykres 4. Stosunek poszczególnych kierunków pochodzenia oleju napędowego do wskaźnika Shannona-Wienera dla ukraińskiego rynku ON

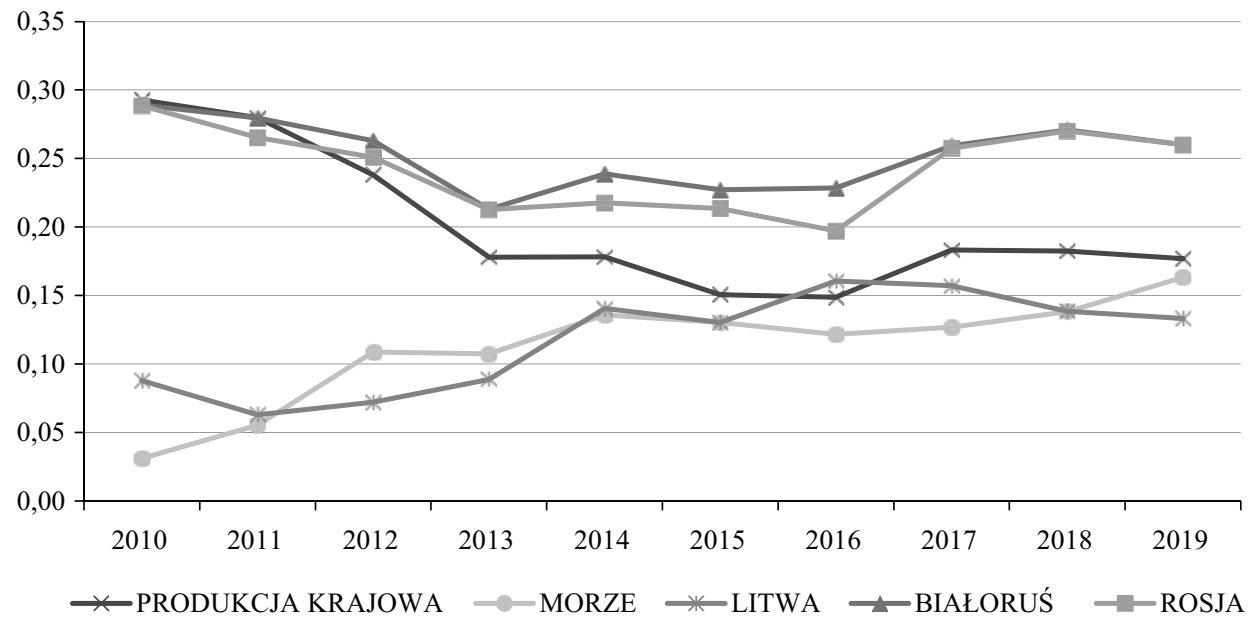

Źródło: opracowanie własne.

Podejmując się próby określenia wpływu, jaki na krajową produkcję ON mogły mieć wydarzenia polityczne z lat 2013-2014, należy zauważyć, że sektor ten zaczął tracić znaczenie już wcześniej, tj. pod koniec 2013 r. (spadek w stosunku

\footnotetext{
${ }^{11}$ Warto zauważyć, że w pierwszym i ostatnim roku badania stosunek SR i SB do SWUA był podobny - po 0,29 w 2010 r. i 0,26 w 2019 r.
} 
do SWUA o $25 \%$, do 0,18 pkt). Wspomniane wydarzenia pogłębiły tylko tę stratę - w latach 2015 i 2016 SPK wynosił już 0,15 pkt, a jednocześnie wskaźnik zróżnicowania rynku SWUA był wyższy niż w 2014 r. (1,61 pkt w 2015 r. i 1,56 pkt w 2016 r. wobec 1,48 pkt w 2014 r.).

Zdecydowany wzrost wpływu na wartość wskaźnika zróżnicowania Shannona-Wienera dla rynku ON Ukrainy odnotował litewski kierunek importu tego paliwa (składnik litewski, SL), który od 2010 r. do końca 2019 r. wzrósł o 44,4\%, z 0,09 pkt do 0,13 pkt (Tabela 1 i Wykres 4). Średni udział SL w SWUA w badanych latach wyniósł 0,12 pkt. Litewski kierunek importu ON na Ukrainę był tym, którego znaczenie najbardziej wzrosło po wybuchu pierwszych demonstracji w Kijowie. Pod koniec 2014 r. wyniósł on o 35,7\% więcej niż rok wcześniej, czyli wzrósł w stosunku do SWUA o 0,05 pkt, do 0,14 pkt. W latach 2015 i 2016 składnik litewski wyniósł kolejno 0,13 pkt i 0,16 pkt. Od roku 2018 zaczął jednak spadać kosztem ponownego wzrostu znaczenia kierunków rosyjskiego i morskiego.

Obszarem o najniższym średnim wpływie na zróżnicowanie rynku ON Ukrainy było w badanym okresie Morze Czarne (składnik morski, SM), jednak to właśnie SM zyskał najwięcej spośród pozostałych składników, bo aż 433,3\% w stosunku do SWUA, czyli wzrósł o 0,13 pkt, do 0,16 pkt na koniec 2019 r. (Tabela 1 i Wykres 4.). Przez cały badany okres znaczenie tego składnika regularnie zwiększało się - w latach 2015 i 2016 osiągnął on kolejno 0,13 pkt i 0,12 pkt.

Wykres 5. Współczynnik Giniego obrazujący zróżnicowanie ukraińskiego importu ON w latach 2010-2019

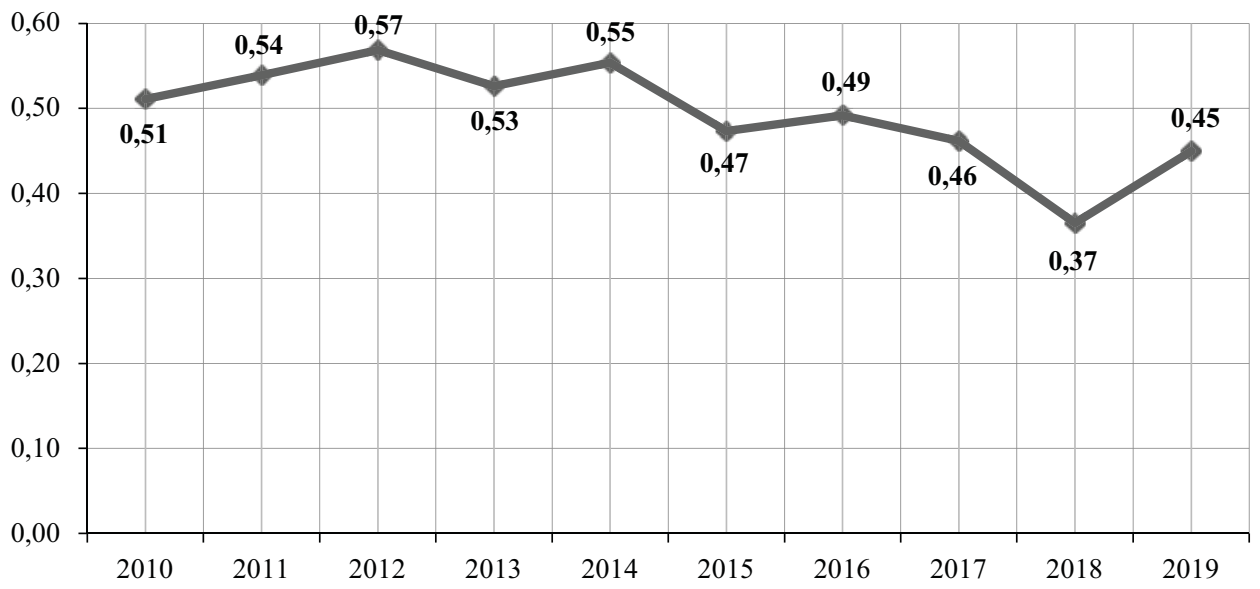

Źródło: opracowanie własne.

Wyniki uzyskane dzięki zastosowaniu współczynnika Giniego w odniesieniu do sektora ukraińskiego importu ON potwierdzają ustalenia SWUA. W badanym okresie doszło do wyraźnego spadku wartości GC - z 0,51 pkt w $2010 \mathrm{r}$. 
do 0,45 pkt na koniec 2019 r., tj. o 11,8\% (Wykres 5), co oznaczało zmniejszenie nierówności w analizowanym układzie. Stało się tak na skutek obniżenia wartości składników rosyjskiego i białoruskiego w stosunku do wskaźnika ShannonaWienera na ukraińskim rynku ON (każdy spadł o 0,03 pkt od 2010 r. do końca 2019 , tj. o 10,3\%) oraz wzrostu składnika litewskiego (o 0,04 pkt, czyli 44,4\%) i morskiego $(0,13 \mathrm{pkt}$, czyli $433,3 \%)$. W analizowanym okresie GC wahał się między 0,37 pkt w 2018 r., kiedy to nierówności w ukraińskim imporcie ON były najniższe, a 0,57 pkt w 2012 r., gdy były najwyższe.

Analiza wyników GC pozwala zauważyć, podobnie jak w przypadku SWUA, zmianę na korzyść zróżnicowania udziałów poszczególnych źródeł oleju napędowego w ukraińskim rynku po wydarzeniach z lat 2013-2014. Pomiędzy rokiem 2014 a 2015 nastąpił drugi najwyższy spadek współczynnika Giniego - z 0,55 pkt do $0,47 \mathrm{pkt}$, tj. o $14,5 \%$. Należy to rozumieć jako znaczący postęp w różnicowaniu dostaw na ukraiński rynek ON, a tym samym w zwiększaniu niezależności rego rynku i ogólnego bezpieczeństwa importu ON. W latach 2016-2018 tylko raz doszło do spadku GC rok po roku - z 0,49 pkt w 2016 r. do $0,37 \mathrm{pkt}$ w 2018 r., tj. o 24,5\%. To pozytywne zjawisko zostało jednak szybko skorygowane - współczynnik nierówności w sektorze ukraińskiego importu ON wzrósł radykalnie pomiędzy rokiem 2018 a 2019 o 21,6\% (do 0,45 pkt). Stało się tak na skutek ogólnego wzrostu wartości SWUA, z 1,35 pkt w 2018 r. do 1,41 pkt na koniec 2019 r., tj. o 4,3\% (Tabela 1), a przede wszystkim składnika morskiego - z 0,14 pkt w 2018 r. do 0,16 pkt w 2019 r.

\section{Wnioski}

Po przeanalizowaniu wskaźnika Shannona-Wienera dla rynku ON Ukrainy oraz współczynnika Giniego odnośnie do ukraińskiego importu tego paliwa w latach 2010-2019 do kluczowych wyzwań dla bezpieczeństwa krajowej podaży ON autor zalicza:

- Stale utrzymujący się wysoki udział w ukraińskim rynku rosyjskiego i białoruskiego kierunku importu ON - pod koniec 2019 r. składniki rosyjski i białoruski odnotowały wartości na poziomie 0,26 pkt w stosunku do wskaźnika Shannona-Wienera dla rynku ON Ukrainy (Tabela 1). Pomimo spadku tej wartości w badanym okresie o 10,3\% (z 0,29 pkt) wspomniane kierunki importu ON dominują w ukraińskim koszyku dostaw ON - SR i SB zajmują po 26,2\% (0,37 pkt) wyniku SWUA. Biorąc pod uwagę argumenty o wpływie strony rosyjskiej na białoruski przemysł rafineryjny, uzasadnione wydaje się sprowadzenie powyższych 
danych do tezy, że pod koniec ubiegłego roku Rosja miała możliwość zarówno bezpośredniego, jak i pośredniego tj. poprzez ingerencję na kierunku białoruskim, wpływania na 52,4\% wartości SWUA. W $2018 \mathrm{r}$. było to $54,1 \%$, a w 2015 r., pierwszym pełnym roku kalendarzowym po wybuchu wojny w Donbasie - 44,1\%.

- Niski poziom zróżnicowania rynku (na koniec 2019 r. SWUA osiągnął wynik $1,41 \mathrm{pkt}$ ), a przede wszystkim niższy niż ten odnotowany po wydarzeniach politycznych z lat 2013-2014. SWUA w 2019 r. był o 12,5\% niższy niż ten z końca 2015 r. (1,61 pkt) (Tabela 1).

- Wysoki poziom nierówności w ukraińskim imporcie ON - współczynnik Giniego pod koniec 2019 r. wynosił 0,45 pkt. Począwszy od 2014 r., GC w miarę regularnie spada (Wykres 5), jednak biorąc pod uwagę skalę negatywnych wydarzeń w relacjach pomiędzy Kijowem a Moskwą, których szczególna eskalacja nastąpiła przed pięcioma laty w efekcie aneksji Krymu i trwa do dzisiaj z powodu walk w Donbasie, znaczenie rosyjskiego kierunku importu ON na Ukrainę powinno ulegać wyraźniejszemu zmniejszeniu.

Mogłoby się wydawać, że po zaostrzeniu relacji na linii Ukraina-Rosja w związku z wydarzeniami politycznymi z lat 2013-2014 stosunki handlowe między tymi państwami wygasną do niezbędnego minimum. Ponadto, wymiana surowców energetycznych czy produktów od nich pochodzących z pewnością nie miałaby się do nich zaliczać. Wzajemne oskarżenia Ukrainy i Rosji o niewywiązywanie się z zobowiązań dotyczących handlu gazem ziemnym elektryzowały europejską opinię publiczną na długo przed aneksją Krymu (Gazprom zapłacił ukraińskiemu Naftohazowi... 27.12.2019). Z upływem czasu faktycznie doszło do pewnego ograniczenia relacji handlowych między tymi państwami. Pod koniec kwietnia 2019 r. pierwsze miejsce Rosji jako głównego importera ukraińskich dóbr zajęła Polska (Trusewicz 17.06.2019). Inaczej zareagował jednak rynek oleju napędowego. Od 2013 r. do końca 2014 r. sprzedaż produkcji rosyjskiej na Ukrainie spadła o 35,2\%, do 1093 kT (Załącznik 2), a następnie, w 2018 r., wzrosła do $2710 \mathrm{kT}$ (Wykres 1), tj. do poziomu znacznie wyższego niż przed wybuchem walk w Donbasie (Kuyun 6.03.2019). Najlepszym symbolem różnic pomiędzy polityką skłóconych państw a ekonomią było uruchomienie w 2016 r. rurociągu Prikarpatzapadtrans. Z każdym kolejnym rokiem dostarczał on na ukraiński rynek coraz więcej rosyjskiego produktu, a pod koniec pierwszej połowy 2019 r. był już jego głównym źródłem dla miejscowych stacji paliw. Fakt, że projekt ten zakończył się sukcesem w tak trudnych politycznie warunkach, tj. już w drugim roku po aneksji Krymu, prowokuje do stwierdzenia, że handel pomiędzy Rosją a Ukrainą jest uzależniony od polityki jedynie do pewnego stopnia. 
Uzyskane wyniki wskaźnika Shannona-Wienera i współczynnika Giniego dowodzą, że ukraiński rynek ON pozostaje uzależniony od Rosji bezpośrednio i pośrednio. Mimo że za pozytywne zjawisko należy uznać ogólny spadek w badanym okresie wartości składnika rosyjskiego w stosunku do SWUA, to ograniczenie przez Białoruś eksportu paliw na Ukrainę na początku 2020 r., będące skutkiem zmniejszenia dostaw rosyjskiej ropy do rafinerii w Mozyrzu i Nowopołocku, wystarczająco obrazuje wpływ, jaki na ukraiński rynek ON może mieć uzależnienie Białorusi od zakupów surowca z Rosji.

W tych okolicznościach autor za w pełni uzasadnione uważa stwierdzenie, że SWUA za ostatnie 12 miesięcy aż w 52,4\% (razem SR i SB) składa się z czynników bezpośrednio bądź pośrednio zależnych od strony rosyjskiej, co potwierdza przyjętą na wstępie hipotezę. Wysoka wartość wskaźnika skoncentrowania udziałów Rosji i Białorusi w ukraińskim rynku ON powinna być traktowana jako fundamentalne wyzwanie dla bezpieczeństwa tego rynku. Wydaje się, że obecna ukraińska struktura konsumpcji i importu ON wymaga pilnej dywersyfikacji. Tylko od 2019 r. nie brakowało sygnałów, że główne problemy tego rynku mają swoje źródła albo poza krajem, np. w nieporozumieniach handlowych między Białorusią a Rosją, albo w czynnikach pozaekonomicznych, np. w trudnych relacjach politycznych z Federacją Rosyjską. Wyraźnym wspólnym mianownikiem tych problemów była Rosja oraz jej silna pozycja jako producenta oleju napędowego czy ropy naftowej. Wydaje się, że najsłuszniejszym posunięciem ukraińskiej władzy byłoby nawiązanie współpracy z biznesem paliwowym w celu przeorientowania importu ON i skupienie się na kierunkach innych niż Rosja i Białoruś (maksymalizowanie zakupów z morza, Litwy bądź poszukiwanie nowych dostawców). Innym wyzwaniem dla krajowej administracji powinna być stopniowa praca nad zwiększaniem produkcji własnej w wyniku modernizacji działających już rafinerii, w Krzemieńczugu i Szebelince, oraz uruchamiania nieczynnych, np. rafinerii w Odessie.

Strona ukraińska analizuje obecnie projekt ustanowienia prawa ograniczającego udział w rynku wewnętrznym paliw importowanych z pojedynczego kierunku do 30\% (Kompanii Kolomojskogo $i$ «doczka»... 21.01.2020). Rozważa także nałożenie kolejnych sankcji na produkcję rosyjską, m.in. dodatkowej taryfy w wysokości 8,46\% na wszystkie trafiające na Ukrainę rosyjskie paliwa silnikowe bez względu na ich kanał transportu («Ukrtatnafta» priedłożyła poszlinu. . . 21.02.2020). To drugie rozwiązanie budzi jednak wątpliwości opinii publicznej oraz firm aktywnych na krajowym rynku paliw. Wynikają one z faktu, że ponad $90 \%$ krajowej produkcji paliw pozostaje pod kontrolą ukraińskiego oligarchy Ihora Kołomojskiego. Inicjatywa ustanowienia dodatkowego cła na rosyjskie paliwa, autorstwa jednej ze spółek należących do ww. biznesmena (Ukrtatnafta), postrzegana jest zarówno jako próba powiększenia przestrzeni rynkowej dla produkcji krajowej, ale również jako próba ochrony interesów oligarchy. Wpływ ukraińskiej oligarchii na krajowy rynek paliw in genere to obszar potencjalnych przyszłych badań. 


\section{Podsumowanie}

Autor ma nadzieję, że artykuł w sposób możliwie czytelny dostarczył informacji dotyczących przyjętego problemu badawczego, a mianowicie sprecyzował poziom zewnętrznej zależności ukraińskiego rynku oleju napędowego od importu tego paliwa z kierunku podatnego na względy polityczne, jakim jest Rosja, oraz z kierunku uzależnionego od silnego rosyjskiego dostawcy ropy naftowej, czyli Białorusi.

Z powodu ograniczonych możliwości krajowej produkcji ON Ukraina zmuszona jest importować to paliwo. Mimo że obecna ukraińska władza wykazuje ambicje dążenia do paliwowej niezależności kraju, to dotychczasowe rezultaty mających do tego doprowadzić prac nadal nie pozwalają na zmniejszenie zależności krajowego rynku ON od rosyjskiego kierunku importu.

Olej napędowy nie jest jedynym paliwem, w przypadku którego dostawy z Rosji są obecnie niezbędne dla bilansowania ukraińskiej konsumpcji. Podobna sytuacja ma miejsce w przypadku LPG, drugiego najpopularniejszego paliwa silnikowego na Ukrainie - pod koniec 2019 r. udział produktu rosyjskiego w ogólnym zużyciu LPG na rynku ukraińskim wyniósł 34\%, tj. 694 kT (Ukraina narastiła import dizielnogo... 12.03.2020). Wewnętrzne zapotrzebowanie Ukrainy na ON napędzane jest, poza transportem, również przez dynamicznie rozwijające się rolnictwo (Rost w sielskom choziajstwie... 18.11.2019). W odróżnieniu więc od LPG, wykorzystywanego na Ukrainie niemal wyłącznie przez transport, ewentualny deficyt oleju napędowego doprowadziłby bezpośrednio do zdecydowanie większej liczby problemów natury gospodarczej, za którymi nieodłącznie maszerują te o charakterze politycznym. Zmiany cen paliw na ukraińskich stacjach, a zwłaszcza tego najpopularniejszego, czyli ON, są stałym elementem walki politycznej pomiędzy władzą a opozycją.

Pracując nad niniejszym artykułem, autor napotkał kilka przeszkód. Główną z nich było dotarcie do wiarygodnych danych, które nierzadko różniły się od siebie w zależności od kraju pochodzenia (Ukraina, Rosja czy Białoruś). Pomimo wszelkiego trudu tematyka rynku paliw Ukrainy jest w ocenie autora interesująca, nie do końca odkryta i gotowa do badania. Do szczególnie ciekawych zagadnień należy zaliczyć wspomniany wpływ ukraińskiej oligarchii na krajowy rynek paliw czy kwestię możliwości ukraińskiego przemysłu rafineryjnego. Z polskiego punktu widzenia istotna byłaby analiza rynku paliw Ukrainy pod kątem bezpieczeństwa energetycznego RP czy UE i to właśnie temu zagadnieniu autor planuje poświęcić swoją dalszą pracę badawczą. Liczy on na to, że zarówno niniejsze opracowanie, jak i kolejne traktujące o kierunku ukraińskim będą interesującą lekturą, która pozwoli pogłębić czytelnikowi wiedzę o gospodarce wschodniego sąsiada Polski. 


\section{凹 Załącznik 1}

Wielkość ukraińskiego rynku paliw silnikowych w latach 2004-2019, w mln t

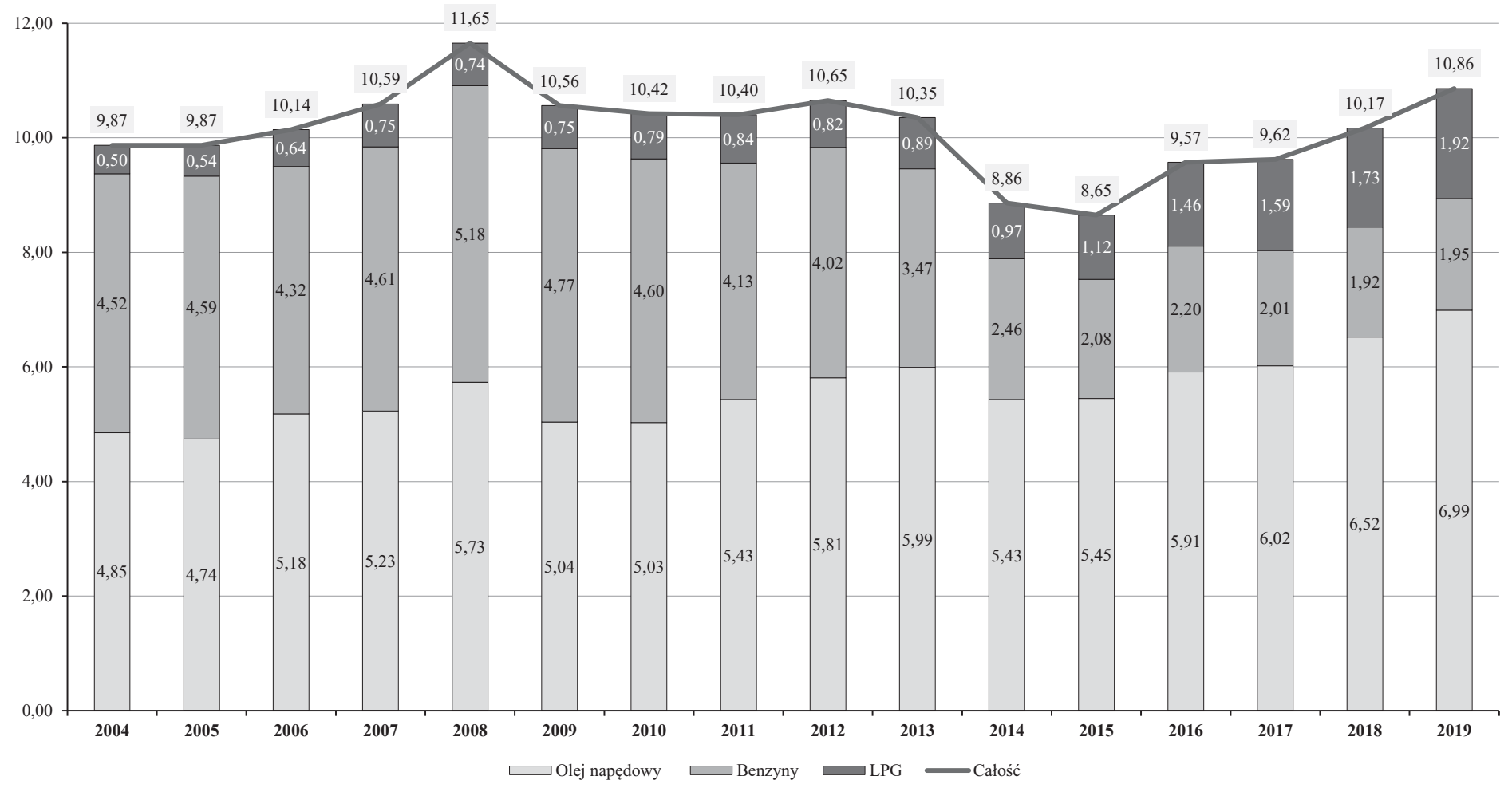

Źródło: opracowanie własne na podstawie Rynok motornogo topliwa... 20.02.2020. 


\section{Załącznik 2}

Źródła pochodzenia oleju napędowego na rynku UA w latach 2010-2019, w kT

\begin{tabular}{|l|r|r|r|r|r|r|r|r|r|r|}
\cline { 2 - 11 } \multicolumn{1}{c|}{ ROK } & $\mathbf{2 0 1 0}$ & $\mathbf{2 0 1 1}$ & $\mathbf{2 0 1 2}$ & $\mathbf{2 0 1 3}$ & $\mathbf{2 0 1 4}$ & $\mathbf{2 0 1 5}$ & $\mathbf{2 0 1 6}$ & $\mathbf{2 0 1 7}$ & $\mathbf{2 0 1 8}$ & $\mathbf{2 0 1 9}$ \\
\hline Produkcja krajowa & 2700 & 1879 & 1113 & 1000 & 700 & 600 & 600 & 750 & 738 & 812 \\
\hline Rosja & 1068 & 1380 & 1286 & 1688 & 1093 & 1334 & 1058 & 1937 & 2710 & 2499 \\
\hline Białoruś & 1075 & 1849 & 2838 & 1705 & 2575 & 2173 & 2724 & 2343 & 2152 & 2470 \\
\hline Litwa & 141 & 117 & 153 & 297 & 457 & 465 & 691 & 567 & 460 & 499 \\
\hline Polska & 0 & 0 & 0 & 95 & 75 & 288 & 109 & 0 & 0 & 0 \\
\hline Morze & 36 & 98 & 275 & 398 & 432 & 465 & 427 & 398 & 459 & 702 \\
\hline Pozostałe & 10 & 103 & 140 & 810 & 100 & 120 & 300 & 25 & 0 & 10 \\
\hline RAZEM & $\mathbf{5 0 3 0}$ & $\mathbf{5 4 2 6}$ & $\mathbf{5 8 0 5}$ & $\mathbf{5 9 9 3}$ & $\mathbf{5 4 3 2}$ & $\mathbf{5 4 4 5}$ & $\mathbf{5 9 0 9}$ & $\mathbf{6 0 2 0}$ & $\mathbf{6 5 1 9}$ & $\mathbf{6 9 9 2}$ \\
\hline
\end{tabular}

Źródło: opracowanie własne na podstawie danych zebranych z historycznych publikacji oraz materiałów enkorr, UPECO, Argus Media i in.

\section{Bibliografia}

4Q2019: EU diesel demand continues to drop while gasoline gains; plug-ins up $80.5 \%$ $y$-o-y (20.02.2020), http://www.greencarcongress.com, http://www.greencarcongress.com/2020/02/20200209-acea.html (data dostępu: 11.03.2020).

Austvik O.G. (2015), The EU Energy Union, Energy Security and Russian Gas, „M-RCBG Associate Working Paper”, nr 51, Mossavar-Rahmani Center for Business and Government, Cambridge.

Bakhtina O., Savosin D. (3.01.2020), Rossija priekratiła postawki niefti na biełorusskije NPZ s 1 janwaria2020 g. No nie do konca, neftegaz.ru, https:// neftegaz.ru/news/Trading/516414-rossiya-prekratila-postavki-nefti-na-belorusskie-npz-s-1-yanvarya-2020-g/ (data dostępu: 12.03.2020).

Biełarus' czasticzno wozobnowiła eksport swietlych nieftieproduktow $w$ Ukrainu i Polszu (25.04.2019), interfax.com.ua, https://interfax.com.ua/news/economic/584062.html (data dostępu: 25.02.2020).

Biełarus' gotowa pokupat' nieft' za priediełami Rossii po mirowym cenam - Łukaszenko (21.01.2020), interfax.by, https://interfax.by/news/policy/ekonomicheskaya_politika/1270236 (data dostępu: 12.03.2020).

Biełarus' priostanowita eksport nieftieproduktow w sosiednije strany. Czto eto znaczit dla Rossii i Ukrainy (23.04.2019), currenttime.tv, http://www.currenttime.tv/a/belarus-petrol-export/29899296.html (data dostępu: 25.02.2020).

Boner B. (22.02.2018), Europejczycy mają dość diesli - to już nie życzenie ekologów, tak wygląda rzeczywistość, moto.pl, https://moto.pl/MotoPL/7,88389, 23052749, europejczycy-maja-dosc-diesli-to-juz-nie-zyczenie-ekologow.html (data dostępu: 11.03.2020). 
Bożyk P., Nyga-Łukaszewska H. (2013), Pojęcie i miary bezpieczeństwa energetycznego, [w:] Bożyk P. (red.), Bezpieczeństwo energetyczne Polski w ujęciu autonomicznym i zintegrowanym z Unia Europejska, Akademia Finansów i Biznesu Vistula, Warszawa.

Burda G. (2.05.2006), Benzyna, olej napędowy czy gaz, motofakty.pl, http://www. motofakty.pl/artykul/benzyna-olej-napedowy-czy-gaz.html (data dostępu: 6.02.2020).

Czech A. (2018), Analiza wybranych wskaźników bezpieczeństwa energetycznego Polski w kontekście zrównoważonego rozwoju, „Studia i Prace WNEIZ US”, nr 53/2, Wydział Nauk Ekonomicznych i Zarządzania Uniwersytetu Szczecińskiego, Szczecin.

Czto izwiestno i czto skrywajut pro griaznuju nieft' $w$ „Drużbie” (8.05.2019), dw.com, http://www.dw.com/ru/что-известно-и-что-скрывают-про-грязную-нефтьвдружбе/a-48660565 (data dostępu: 22.02.2020).

Dronowa A.J. (2010), Analiz postawok palnoho na rynku naftoproduktiw Ukrajiny: importnyj aspekt [w:] Mechanyzm Rehuluwannia Ekonomyky, Sumski Uniwersytet Państwowy, Sumy.

DT dieszewiejet w ożydanii zapuska «truby» (6.12.2019), enkorr.ua, https://enkorr. ua/ru/news/DT_desheveet_v_ozhidanii_zapuska_trubi/239361 (data dostępu: 16.02.2020).

Energy consumption in transport (17.12.2019), eea.europa.eu, https://www.eea. europa.eu/data-and-maps/daviz/transport-energy-consumption-eea5\#tabgooglechartid_googlechartid_chart_111 (data dostępu: 11.03.2020).

Furman T. (30.09.2018), Rynek paliw w UE mocno się zmienia, parkiet.com, https:// www.parkiet.com/Parkiet-PLUS/309309988-Rynek-paliw-w-UE-mocno-sie-zmienia.html (data dostępu: 11.03.2020).

Gazprom zapłacit ukraińskiemu Naftohazowi 2,9 mld USD odszkodowania (27.12.2019), pb.pl, https://www.pb.pl/gazprom-zaplacil-ukrainskiemu-naftohazowi-29-mld-usd-odszkodowania-978602 (data dostępu: 20.03.2020).

Import diztopliwa $w$ ijule obnowit riekord: 658,5 tys. $t$-UPECO (5.08.2019), nefterynok.info, https://www.nefterynok.info/novosti/import-dt-v-iyule-dostig-rekordnyh-6585-tys-t--upeco (data dostępu: 14.02.2020).

Kamiński J. (2009), Metody szacowania siły rynkowej w sektorze energetycznym, „Polityka Energetyczna - Energy Policy Journal”, t. 12, z. 2, Polska Akademia Nauk.

Kompanii Kołomojskogo $i$ «doczka» Naftogaza triebujut wwiesti poszliny na rossijskije diztopliwo i awtogaz (21.01.2020), nv.ua, https://nv.ua/biz/markets/ kompanii-kolomoyskogo-i-naftogaza-trebuyut-vvesti-poshliny-narossiyskie-dt-i-avtogaz-novosti-ukrainy-50065413.html (data dostępu: 16.03.2020).

Korrupcyja w portach i zloupotrieblenija ekoinspiekcyi -fragmient głobalnoj korrupcyi - ekonomist (17.07.2019), unian.net, https://www.unian.net/ 
ecology/10620291korrupciya-v-portah-i-zloupotrebleniya-ekoinspekcii-fragment-globalnoy-korrupcii-ekonomist.html (data dostępu: 13.03.2020).

Kryzia D. (2016), Poziom konkurencji na światowym rynku gazu ziemnego, „Polityka Energetyczna - Energy Policy Journal”, t. 19, z. 2, Polska Akademia Nauk.

Kuyun S. (6.03.2019), Kakdosticz ,dizielnogo” bałansa, zn.ua, https://zn.ua/ energymarket/kak-dostich-dizelnogo-balansa-311016_html (data dostępu: 20.03.2020).

Matwijczuk N. (2018), Zahrozy enerhetycznij bezpeci Ukrajiny, „Ekonomicznyj czasopys Schidnojewropejśkoho Nacionalnoho Uniwersytetu imeni Łesi Ukrajinky", nr 13.

Mazur I.M. (2014), Kryteriji ociniuwannia enerhetycznoji bezpeky: resursnyj pidchid, ,Aktualni problemy rozwytku ekonomiky rehionu”, nr 10, Prykarpatskyj Nacionalnyj Uniwersytet imeni Wasyla Stefanyka.

Mirkiewicz D. (9.12.2019), Niemcy walcza z emisja CO2: Ogromny wzrost cen paliw i ograniczenia prędkości na autostradach, motohigh.pl, https://motohigh.pl/2019/12/09/niemcy-emisja-co2-transport-pakiet-klimatyczny-2030 (data dostępu: 11.03.2020).

Młynarski T. (2011), Bezpieczeństwo energetyczne w pierwszej dekadzie XXI wieku. Mozaika interesów i geostrategii, Wydawnictwo Uniwersytetu Jagiellońskiego, Kraków.

Mrówka A. (2012), Bezpieczeństwo energetyczne Polski po przystapieniu do UE. Stan obecny, [w:] Wojtkowska-Łodej G. (red.), Rola energii we wspótczesnej gospodarce, Oficyna Wydawnicza Szkoła Główna Handlowa, Warszawa.

Muravskij A. (27.08.2019), Kak topliwnyje sankcyi powlijajut na zagruzku ukrainskich nieftietierminatow, ports.com.ua, https://ports.com.ua/articles/kak-toplivnye-sanktsii-povliyayut-na-zagruzku-ukrainskikh-nefteterminalov (data dostępu: 16.02.2020).

Nyga-Łukaszewska H. (2019), Bezpieczeństwo energetyczne na międzynarodowym rynku gazu ziemnego, Oficyna Wydawnicza SGH, Warszawa.

Omielan i Gierus rasskazali o diwiersifikacyi postawok diztopliwa w Ukrainu w swiazi s ograniczenijami RF (6.08.2019), cfts.org.ua, https://cfts.org.ua/ news/2019/08/06/omelyan_i_gerus_rasskazali_o_diversifikatsii_postavok diztopliva_v_ukrainu_v_svyazi_s_ogranicheniyami_rf_54582 (data dostępu: 12.03.2020).

POPiHN: Zużycie paliw w Polsce wyniosto $34,76 \mathrm{mln}^{3}$ w 2019, wzrost o 4\% $r: r$ (7.04.2020), forsal.pl, https://forsal.pl/artykuly/1467640,popihn-zuzycie-paliw-w-polsce-wynioslo-34-76-mln-m3-w-2019-wzrost-o-4-r-r.html (data dostępu: 8.04.2020).

Port Odiessy wiernut pierwienstwo po importu nieftieproduktow za sczet «Karpatnieftiechima» (16.07.2019), enkorr.ua, https://enkorr.ua/ru/news/ 
Port_Odessi_vernul_pervenstvo_po_importu_nefteproduktov_za_schet_ Karpatneftehima/237530 (data dostępu: 13.03.2020).

Poszliny nie priwiedut $k$ rostu cen na AZS, no sozdajut riski w prieddwierii pikowogo siezona potrieblenija - ekspiert (18.07.2019), enkorr.ua, https:// enkorr.ua/ru/news/Polshini_ne_privedet_k_rostu_tsen_na_AZS_no_sozdayut_riski_v_preddverii_pikovogo_sezona_potrebleniya_\%E2\%80\%93_ekspert/237582 (data dostępu: 14.02.2020).

Pronińska K. (2013), Wpływ wspótpracy energetycznej krajów Europy Środkowej na regionalne bezpieczeństwo energetyczne i politykę energetyczna UE, Centrum Europejskie Natolin, Warszawa.

Prontera A. (2009), Energy Policy: Concepts, Actors, Instruments and Recent Developments, „World Political Science Review”, t. 1, nr 1, International Political Science Association.

Rodriguez-Fernandez L., Fernandez Carvajal A.B., Ruiz-Gomez L.M. (2020), Evolution of European Union's energy security in gas supply during Russia-Ukraine gas crises (2006-2009), „Energy Strategy Reviews”, nr 30, Elsevier.

Rossija kompiensirowata spad postawok diztopliwa Izbiełarusi (11.03.2020), enkorr.ua, https://enkorr.ua/ru/news/rossiya_kompensirovala_spad_postavokdiztopliva_iz_belarusi/240576 (data dostępu: 16.03.2020).

Rostw sielskom choziajstwie Ukrainyzamiedlitsia (18.11.2019), rbc.ua, https://www. rbc.ua/rus/news/rost-selskom-hozyaystve-ukrainyzamedlilsya1574087628. html (data dostępu: 20.03.2020).

Rynok motornogo topliwa dostig maksimuma za 10 let (20.02.2020), enkorr.ua, https://enkorr.ua/ru/news/rynok_motornogo_topliva_dostig_maksimuma za_10_let $/ 239820$ (data dostępu: 16.03.2020).

Sauvageot E.P. (2020), Between Russia as producer and Ukraine as transit country: EU dilemma of interdependence and energy security, „Energy Policy”, $\mathrm{nr}$ 145, Elsevier.

Skywalk i BB Energy postawiat w Jużnyj 27tys. t DT (19.08.2019), enkorr.ua, https://enkorr.ua/ru/news/Skywalk_i_BB_Energy_postavyat_v_Yuzhniy_27 tis_t_DT/237970 (data dostępu: 13.03.2020).

Teletow O.S., Klymenko W.W. (2013), Analiz tendencij rozwytku rynku dyzelnoho paliwa, „Marketynh i menedżment innowacij”, $\mathrm{nr} 1$.

Tomaszewski K. (2014), Bezpieczeństwo energetyczne państwa [w:] Sulowski S., Brzeziński M. (red.), Trzy wymiary wspótczesnego bezpieczeństwa, Dom Wydawniczy Elipsa, Warszawa.

Trusewicz I. (17.06.2019), Polska wyprzedziła Rosję w imporcie produkcji z Ukrainy, rp.pl, https://www.rp.pl/Handel/190619499 (data dostępu: 20.03.2020).

Ukraina narastita import dizielnogo topliwa iz Rossii na 40\% - SMI(12.03.2020), epravda.com.ua, http://www.epravda.com.ua/rus/news/2020/03/12/657956 (data dostępu: 20.03.2020). 
Ukrainskij rynok DT priblizitsia $k 7$ mtn (13.01.2020), enkorr.ua, https://enkorr. ua/ru/news/ukrainskiy_rynok_dt_priblizilsya_k_7_mln_t/239721 (data dostępu: 12.02.2020).

Ukrainskij rynok sżyżennogo gaza priewysit 2 mitliona tonn (11.01.2020), epravda.com.ua, http://www.epravda.com.ua/rus/news/2020/01/11/655679 (data dostępu: 11.03.2020).

«Ukrtatnafta» priedlożyła poszlinu w razmierie 8,46\% (21.02.2020), nefterynok. info, http://www.nefterynok.info/novosti/ukrtatnafta-predlojila-poshlinu-v-razmere-846 (data dostępu: 16.03.2020).

Własiuk O.S. (2016), Nacionalna bezpeka ukrajiny: ewolucija problem wnutrisznioji polityky - wybrani naukowi praci, Nacionalnyj Instytut Stratehicznych Doslidżen, Kijów.

\section{Streszczenie}

Celem niniejszego artykułu jest przedstawienie obecnej sytuacji na ukraińskim rynku oleju napędowego ze szczególnym uwzględnieniem zagrożeń wynikających z jego ograniczonej autonomii. Rynek ten pozostaje wyjątkowo wrażliwy - olej napędowy jest najpopularniejszym paliwem silnikowym wśród mieszkańców tego kraju, jednak jego dostawy są silnie powiązane z wydarzeniami z udziałem Rosji, które z reguły mają negatywny wpływ na jego płynność. Przejawiało się to szczególnie wyraźnie w relacjach rynkowych między Ukrainą, Rosją a Białorusią w roku 2019 i na początku roku 2020.

Na podstawie analizy wskaźnika Shannona-Wienera dla ukraińskiego rynku oleju napędowego oraz współczynnika Giniego dotyczącego importu przez Ukrainę tego paliwa autor pozytywnie weryfikuje hipotezę zakładającą, że fundamentalnym wyzwaniem dla bezpieczeństwa rynku ON Ukrainy pozostaje duży udział w nim paliwa z Rosji i Białorusi (łącznie 52,4\%). Z badania wynika, że Ukraina powinna wykorzystywać wszelkie możliwości rynkowe oraz narzędzia prawne, aby minimalizować wyraźny wpływ swojego wschodniego sąsiada na bezpieczeństwo rynku ON.

Słowa kluczowe: rynek oleju napędowego Ukrainy, dywersyfikacja importu paliw, współczynnik Giniego, wskaźnik Shannona-Wienera 


\section{Summary}

\section{The issue of Ukraine's dependence on diesel imports}

This paper aims to present the current situation on the Ukrainian market of diesel fuel with particular regard to the risks that arise from its limited autonomy. The abovementioned market remains extremely sensitive for Ukraine - diesel is the most popular type of motor fuel among the inhabitants of this country. At the same time, the Ukrainian diesel market is not free from the effects of events involving Russia, which are quickly damaging its current liquidity. This seemed to be even more pronounced from the perspective of market events in 2019 and early 2020 that took place in relations between Ukraine, Russia and Belarus.

By analysing the Shannon-Wiener index for the Ukrainian diesel market, and the Gini coefficient for Ukraine's import of this fuel, the author positively verifies the hypothesis that the high concentration of the share of diesel from Russia and Belarus remains a fundamental challenge for the security of the Ukrainian market of this fuel (52.4\% in total). As a result of the study, the author concludes that the country should use all market opportunities and legal tools to minimise the clear impact of its eastern neighbour on the security of its diesel market.

Keywords: Ukrainian diesel market, diversification of fuel import, Gini Coefficient, Shannon-Wiener Index

JEL: F50, Q41 